\title{
Seroprevalence rates of antibodies against Theileria equi in team roping horses from central-western region of Paraná
}

\author{
Soroprevalência de anticorpos contra Theileria equi em equinos atletas da regiáo centro-oeste do Paraná \\ Hanna Carolina Prochno ${ }^{1}$; Lucas Milléo Scorsin ${ }^{1}$; Fatiane Rodrigues De Melo ${ }^{1}$; Cristiane Divan Baldani² \\ Margarete Kimie Falbo ${ }^{1}$; Lucia Cury Thomaz de Aquino ${ }^{3}$; Karen Regina Lemos ${ }^{1 *}$ \\ ${ }^{1}$ Departamento de Medicina Veterinária, Universidade Estadual do Centro-Oeste do Paraná - UNICENTRO, Guarapuava, PR, \\ Brasil \\ ${ }^{2}$ Instituto de Veterinária - DMCV, Universidade Federal Rural do Rio de Janeiro -UFRRJ, Seropédica, RJ, Brasil \\ ${ }^{3}$ Médico Veterinário autônomo, Campinas, SP, Brasil
}

Received May 15, 2013

Accepted December 13, 2013

\begin{abstract}
The purpose of this study was to estimate the prevalence of Theileria equi in horses from central western region of Paraná state, Brazil. The presence of antibodies IgG against T. equi was determined in serum samples obtained from 400 team roping horses of the district of Guarapuava by the enzyme-linked immunosorbent assay (ELISA). Results showed that $242(61 \%)$ animals were positive which demonstrates that equine piroplasmosis is widespread and therefore it might be a contributing factor for the irregular performance among athletes horses in the region studied. No association regarding age and sex were observed ( $\mathrm{p}>0.05)$. To our knowledge, this is the first report describing a serological survey on equine piroplasmosis in the state of Paraná, Brazil.
\end{abstract}

Keywords: Theileria equi, horses, ELISA.

\section{Resumo}

O objetivo deste estudo foi estimar a prevalência de Theileria equi em equinos da região centro-oeste do Estado do Paraná, Brasil. A presença de anticorpos IgG contra T. equi foi determinada em amostras de soro obtidas a partir de 400 cavalos atletas do distrito de Guarapuava pelo ensaio imunoenzimático (ELISA). Os resultados mostraram que $242(61 \%)$ animais foram positivos, o que demonstra que a piroplasmose equina apresenta ampla distribuição e, portanto, poderá contribuir para a performace irregular de cavalos que participam de eventos desportivos na região. Não foi observada associação com a idade ou sexo dos equinos ( $p>0,05)$. Pelo que se sabe, este é o primeiro relato de levantamento sorológico sobre piroplasmose equina no Estado do Paraná, Brasil.

Palavras-chaves: Theileria equi, horses, ELISA.

Equine piroplasmosis, caused by Theileria equi and Babesia caballi, has emerged as an important protozoan infection from the veterinary and economic viewpoints. The disease is generally characterized by fever, anemia, icterus, prostation, hepato and splenomegaly, intravascular hemolysis, hemoglobinuria and bilirrubinuria and in some cases, can lead to death (SCHEIN, 1988). However, clinical signs are not pathognomonic and may vary from asymptomatic to acute, being most of the times variable and non-specific (DE WAAL, 1992). Indeed, most of the horses act as carriers of the parasite for several years, becoming reservoirs

\footnotetext{
*Corresponding author: Karen Regina Lemos

Departamento de Medicina Veterinária, Universidade Estadual do

Centro-Oeste do Paraná - UNICENTRO, Rua Simeão Camargo Varela de Sá,

03, Campus CEDETEG, CEP 85040-080, Guarapuava, PR, Brasil

e-mail: klemos@unicentro.br
}

for vector ticks (KNOWLES et al., 1996; CACCIO et al., 2000). To date, three distinct genera of ticks (Dermacentor, Hyalomma and Rhipicephalus) have been identified in T. equi transmission (MEHLHORN; SCHEIN, 1998).

The disease has a worldwide distribution and is endemic in most tropical and subtropical areas as well as in some temperate zones of the world (SCHEIN, 1988; DE WAAL, 1992; BRUNING, 1996). It has caused important economic losses in the horse industry, being a serious threat to the horse raising industry and international movement of horses (FRIEDHOFF et al., 1990). Previous studies have demonstrated losses due to treatment costs, recuperation time and low athletic performance (GARCÍASANMARTÍN et al., 2008). In addition, equine piroplasmosis creates difficulty in animals trading and restrictions regarding import/export of animals, as well as participation in international 
competitions, given that infected animals are prevented from entering countries that are disease-free (FRIEDHOFF et al., 1990; KNOWLES, 1996).

In Brazil, T. equi is considered endemic due to high levels of tick infestation on horses. Previous studies in southern and central areas of the country have reported occurrences varying from $49.2 \%$ to $100 \%$ (HEUCHERT et al., 1999; CUNHA et al., 1996; LABRUNA et al., 2001; XUAN et al., 2001; BALDANI et al., 2004, 2010; HEIM et al., 2007).

In the light of reports of irregular performance among athlete horses in the central-western region of Paraná, the aim of the present study was to determine the occurrence of T. equi infections by Enzyme-linked Immunosorbent Assay (ELISA) in horses among team roping from the municipality of Guarapuava, state of Paraná, Brazil.

A total of 400 team roping horses from Guarapuava district, central-western of Paraná State (with an south latitude $25^{\circ} 23^{\prime} 26^{\prime \prime}$, west longitude $51^{\circ} 27^{\prime} 15^{\prime \prime}$ and altitude of $1,116.5 \mathrm{~m}$ ) were randomly selected, in which breeds comprised American quarter and Criollo, being 195 female and 205 male, independent of age. For analyses, the factors age ( $<12$ months; $1-5$ years; $5-10$ years; and $>10$ years) and gender were considered. The study was carried out between January of 2005 and December of 2007. Serum samples were subjected to an Enzyme-linked Immunosorbent Assay (ELISA) to detect IgG antibodies against T. equi as described by Baldani et al. (2004).

ELISA antigen was obtained from a splenectomized horse with the T. equi Jaboticabal strain (GenBank acession number: DQ250541). During the peak of parasitaemia ml of blood was collected in an equal volume of Alsever solution, approximately $80 \%$ of erythrocytes were infected. The blood was diluted 1:4 in normal saline and the infected erythrocytes subjected to lyses with ammonion chloride (MACHADO et al., 1994). T. equi free merozoites were disrupted by nine freezing $\left(-70^{\circ} \mathrm{C}\right) /$ thawing cycles $\left(37^{\circ} \mathrm{C}\right)$, lyophilized and stored at $-70^{\circ} \mathrm{C}$ until required for the ELISA test.

Ninety-six-well microtitration plates (Nunclon ${ }^{\mathrm{TM}}$ Surface; Nunc, Denmark) were coated overnight at $4^{\circ} \mathrm{C}$ with $100 \mu \mathrm{L}$ $(10 \mu \mathrm{g} / \mathrm{mL})$ of crude T. equi antigen diluted in a sodium bicarbonatecarbonated $0.05 \mathrm{M}$ buffer ( $\mathrm{pH}$ 9.6). After overnight incubation at $4^{\circ} \mathrm{C}$, the excess of antigen was removed by three washes with PBS Tween-80 at $0.05 \%$. To reduce non-specific binding, the plates were blocked with $200 \mu$ of PBS Tween-80 containing 6\% skim milk for 2 hours at $37^{\circ} \mathrm{C}$. The blocking agent was removed, and individual horse serum diluted 1:100 in PBS Tween-80 with 5\% skim milk (PBS-TW-SM) was added to each well and then incubated for 90 minutes at $37^{\circ} \mathrm{C}$. Unbound antibodies were removed by washing the plates as described above. One hundred $\mu$ l of alkaline phosphatase conjugated anti-horse IgG (Sigma Chemical Co.) diluted 1:15000 in PBS-TW-SM were added to each well and then incubated for 90 minutes at $37^{\circ} \mathrm{C}$. The plates were washed and the appropriate substrate ( $\mathrm{p}$-nitrophenyl phosphate) was added. Absorbance at $405 \mathrm{~nm}$ was read after 45 minutes incubation at room temperature using an ELISA reader (Dynex Technologies).

The immunological activity of each serum was calculated by determining the sample to positive serum ratio $(\mathrm{S} / \mathrm{P})$, considering positive and negative sera as reference, using the following equation: (mean sample absorbance - mean absorbance of negative serum reference) $/$ (mean absorbance of positive reference serum - mean absorbance of negative serum reference) (MACHADO et al., 1997). S/P values were grouped into ELISA levels (EL), which ranged from 0 (lowest level) to 9 (highest level). The discriminant absorbance value (cut-off) was determined as being two and a half times the mean absorbance value of the negative group. Horses were considered to be positive when $\mathrm{S} / \mathrm{P}$ values at an optical density of $405 \mathrm{~nm}$ were equal or greater than $0.278(\mathrm{EL}=2)$.

The T.equi positivity in the horses, as determined by ELISA, was tested for association with age and gender using the chi-squared or Fisher's exact tests at a 5\% significance level.

Equine piroplasmosis is an important disease especially for horses that travel to equestrian sporting events. Moreover, economic losses due to low performance associated to the disease should be considered. In the present study, 242 (61\%) samples were serological positive for $T$. equi. These results shows that T. equi is widespread in the region studied, suggesting high levels of transmission. Additionally, our data is in accordance with previous studies which have demonstrated that the disease is endemic in Brazil (CUNHA et al., 1996; BALDANI et al., 2004; HEIM et al., 2007; SANTOS et al., 2011; PECKLE et al., 2013). To our knowledge, this is the first report of the detection of IgG antibodies anti-T. equi in Paraná state.

The variables inherent to equines, such as gender and age, were not associated with T. equi positivity ( $p>0.05)$, as 127 male and 125 female were positive. The lack of association with gender is consistent with other studies (SHKAP et al., 1998; SOUZA et al., 2000; BOTTEON et al., 2002; KOUAM et al., 2010). Considering age, seropositivity was found in 82 animals with $1-5$ years; $1225<10$; and $38 \geq 10$ years. The lack of association between age and T. equi is consistent with several reports in the literature (SHKAP et al., 1998; SOUZA et al., 2000; BOTTEON et al., 2002; MORETTI et al., 2010). However, other studies found inconsistent results (RÜEGG et al., 2007; KOUAM et al., 2010), what could be explained in part by different age categorization.

Several authors have demonstrate that the prevalence rates for T. equi ranges from 17 to $100 \%$, according to the region studied and to the diagnosis method applied (PFEIFER BARBOSA et al., 1995; HEUCHERT et al., 1999; KERBER et al., 1999, 2009; XUAN et al., 2001). The overall prevalence of $61 \%$ of equine piroplasmosis in the present study is relatively high and is in accordance with other studies performed in the southern region of Brazil. Cunha et al. (1996) in Rio Grande do Sul state reported the occurrence of antibodies anti-T. equi by indirect fluorescent antibody test (IFAT) in 57.8\% of the horses from Pelotas Jockey Club and two farms. On the plateau of Santa Catarina, Souza et al. (2000) observed that the prevalence of T. equi by IFAT was $50.3 \%$.

However, in southeastern Brazil the occurrence of T. equi is much higher. In the state of São Paulo, Xuan et al. (2001) and Baldani et al. $(2004,2010)$ reported a prevalence of $81 \%, 75 \%$ and $100 \%$ by ELISA for T. equi, respectively. Pfeifer Barbosa et al. (1995), using the IFAT, also observed a prevalence of $100 \%$ for T. equi in horses of Rio de Janeiro state. Furthermore, Bittencourt et al. (1997) found that the prevalence was $84.6 \%$, using the complement fixation test (CFT) in horses of the same state. Heim et al. (2007) reported seroprevalence of $91.0 \%$ by IFAT 
for T. equi in samples collected from horses at a slaughterhouse in the state of Minas Gerais, southeast Brazil.

The differences observed in the seropositivity of T. equi might be a result of different serological tests used. Several studies have showed the low sensitivity and specificity of CFT in identifying equine piroplasmosis carriers, and while they rarely give false positive results, it may occasionally result in a negative response in horses with latent infections (WEILAND, 1986). IFAT, on the other hand, is more sensitive than CFT and rarely renders false negative results (TENTER; FRIEDHOFF, 1986), however standardization is difficult, considering the subjectivity of the reader in assessing the results (BOSE, 1995; BRUNING, 1996). Therefore, ELISA is nowadays an alternative for increased specificity and sensitivity in the detection of acute and latent babesial infections (XUAN et al., 2001; HIRATA et al., 2003; KUMAR et al., 2003; BALDANI et al., 2007). It should be mentioned that T. equi antigen used in the present study, was produced using a very simple methodology and required little material manipulation at a very low cost. Additionally, a previous study have demonstrated that an ELISA with crude soluble antigen was $100 \%$ sensitive and specific (BALDANI et al., 2004). Also important, in the present study the antigens was obtained from a Brazilian T. equi strains, which eliminates possible antigenic differences existent between isolates from different regions (KUTTLER et al., 1988).

Another possible explanation for the differences in the seroprevalence rates of $T$. equi might be related to the restriction of the living area of the horses, especially considering presence of tick vectors. In one previous report (BALDANI et al., 2010) the high positivity rate for T. equi was attributed to the management of horses, which appears to be an important factor for the prevalence of T. equi infections. Additionally, climatic factors such as temperature, relative humidity, altitude and high rainfall influence the habitat of the main tick/vector species that parasite horses (GOLYNSKI et al., 2008). It has been demonstrated that when horses have direct or indirect contact with cattle and there is no rigorous tick control program, T. equi infection rates are much higher (HEUCHERT et al., 1999; KERBER et al., 1999).

In Latin America, horses are regularly infested with three species of ticks: Dermacentor nitens, Rhipicephalus (Boophilus) microplus, and Amblyomma cajennense (BORGES; LEITE, 1998; LABRUNA et al., 2001; DA COSTA PEREIRA et al., 2005). $R$. (B.) microplus has been implicated as a vector of T. equi (GUIMARÃES et al., 1998; UETI et al., 2008), while the role of D. nitens in its transmission has not been reported (DENNING, 1988). As so, the lower prevalence observed in the region of the present study compared to southeastern regions of Brazil may be due to the conditions encountered by tick vectors which are less favorable for their development and reproduction, contributing therefore for lower tick infestation (DAVEY; COOKSEY 1989; CHACÓN et al., 2003). It should be mentioned that the municipality of Guarapuava, which is located in the high-altitude region of the state of Paraná, has a humid semitropical climate, with an annual average temperature of approximately $16^{\circ} \mathrm{C}$, with winter temperatures that reach bellow $0{ }^{\circ} \mathrm{C}$. Peckle et al. (2013) also reported lower infection frequency of T. equi in horses of Petrópolis, a region of Rio de Janeiro state with high altitude, where the annual average temperature is $16{ }^{\circ} \mathrm{C}$ and winter temperatures of $0{ }^{\circ} \mathrm{C}$.

In conclusion, this study reports the occurrence of antibody seroreactivity against T. equi in team hoping horses of Guarapuava, central-western region of Paraná state. Accurate diagnosis of equine piroplasmosis is essential for providing baseline information about its epidemiology, distribution and prevalence in the affected equine population, and is thus a prerequisite for elaborating appropriate and effective control measures. The overall T. equi seroprevalence of $61 \%$ showed here could be related to irregular performance among athletes horses.

\section{Acknowledgments}

Rosangela Zacarias Machado for providing the Laboratory of Animal Parasitology UNESP - Jaboticabal, SP.

\section{References}

Baldani CD, Machado RZ, Botteon PTL, Takakura FS, Massard CL. An enzyme-linked immunosorbent assay for the detection of IgG antibodies against Babesia equi in horses. Cienc Rural 2004; 34(5): 1525-1529. http://dx.doi.org/10.1590/S0103-84782004000500031

Baldani CD, Machado RZ, Raso TF, Pinto AA. Serodiagnosis of Babesia equi in horses submitted to exercise stress. Pesq Vet Bras 2007; 27: 179183. http://dx.doi.org/10.1590/S0100-736X2007000400009

Baldani CD, Nakaghi AC, Machado RZ. Occurrence of Theileria equi in horses raised in the Jaboticabal microregion, São Paulo State, Brazil. Rev Bras Parasitol Vet 2010; 19(4): 228-232. PMid:21184699. http:// dx.doi.org/10.1590/S1984-29612010000400007

Bittencourt VREP, Massard CL, Massard CA. Aspectos epidemiológicos da babesiose equina na microrregiáo fluminense do Grande Rio - Itaguaí, Estado do Rio de Janeiro. Rev Bras Ciênc Vet 1997; 4(1): 13-17.

Borges LMF, Leite RC. Ixodological populations of the ears of equines in Minas Gerais and Bahia, Brazil. Arq Bra Med Vet Zootec 1998; 50(1): 87-89.

Bose R, Jorgensen WK, Dalgliesh RJ, Friedhoff KT, De Vos AJ. Current state and future trends in the diagnosis of babesiosis. Vet Parasitol 1995; 57(1-3): 61-74. http://dx.doi.org/10.1016/03044017(94)03111-9

Botteon PTL, Massard, CL, Botteon, RCM, Loss ZG, Linhares, GF. Seroprevalencia de Babesia equi en tres diferentes sistemas de crianza de equinos: Rio de Janeiro, Brasil. Parasitol latinoam 2002; 57(3-4): 141145 .

Bruning A. Equine piroplasmosis an update on diagnosis, treatment and prevention. BrVet J 1996; 152(2): 139-151. http://dx.doi.org/10.1016/ S0007-1935(96)80070-4

Caccio S, Camma C, Onuma M, Severini C. The beta-tubulin gene of Babesia and Theileria parasites is an informative marker for species discrimination. Int J Parasitol 2000; 30(11): 1181-1185. http://dx.doi. org/10.1016/S0020-7519(00)00105-3

Chacón SC, Correia PG, Barbieri FS, Daemon E, Faccini JLH. Efeito de três temperaturas constantes sobre a fase não parasitária de Amblyomma cajennense (Fabricius, 1787) (Acari: Ixodidae). Rev Bras Parasitol Vet 2003; 12(1): 13-20. 
Cunha CW, Da Silva SS, Pimentel CA, Dapper E. Avaliação da frequência de equinos soropositivos a Babesia equi no Jóquei Clube de Pelotas e em dois Haras da zona sul do Rio Grande do Sul, RS. Rev Bras Parasitol Vet 1996; 5(2): 119-122.

Da Costa Pereira MAV, Massard CL, Faccini JLH, Siqueira LFG. Variação da sorotitulação ao teste de Fixação de Complemento para Babesia equi e Babesia caballi em equinos da regiáo Serrana do Rio de Janeiro. Ars Vet 2005; 21(3): 338- 343 .

Davey RB, Cooksey LM. Effects of prolonged exposure at low temperature on Boophilus microplus (Acari: Ixodidae). J Med Entomol 1989; 26(5): 407-410. PMid:2795611.

De Waal DT. Equine piroplasmosis: a review. Br Vet J 1992; 148(1): 6-14. http://dx.doi.org/10.1016/0007-1935(92)90061-5

Denning F. Unsuccesfull attemps to transmit Amblyomma cajennense [Tese]. Hannover: Leibniz Universitat Hannover; 1988.

Friedhoff KT, Tenter AM, Muller I. Haemoparasites of equines: impact on international trade of horses. Rev Sci Tech 1990; 9(4):1187-1194. PMid:2132711.

García-Sanmartín JFJ, Barandika RA, Juste AL, García-Pérez, Hurtado A. Distribution and molecular detection of Theileria and Babesia in questing ticks from northern Spain. Med Vet Entomol 2008; 22(4): 318-325. PMid:19120958. http://dx.doi.org/10.1111/j.1365-2915.2008.00748.x

Golynski AA, Fernandes KR, Baldani CD, Golynski AL, Madeiro AS, Machado RZ, et al. Estudo soroepidemiológico da Babesia equi em equinos do Estado do Rio Grande do Sul, Brasil determinado pelos testes de imunofluorescência indireta e ELISA. Rev Bras Parasitol Vet 2008; 17(S1):317-321. PMid:20059868.

Guimarães AM, Lima JD, Ribeiro MFB. Sporogony and experimental transmission of Babesia equi by Boophilus microplus. Parasitol Res 1998; 84(4):323-327. PMid:9580425. http://dx.doi.org/10.1007/ s004360050404

Heim A, Passos LM, Ribeiro MF, Costa-Júnior LM, Bastos CV, Cabral DD, et al. Detection and molecular characterization of Babesia caballi and Theileria equi isolates from endemic areas of Brazil. Parasitol Res 2007; 102(1): 63-68. PMid:17828553. http://dx.doi.org/10.1007/ s00436-007-0726-1

Heuchert CM, De Giulli V Jr, De Athaide DF, Böse R, Friedhoff KT. Seroepidemiologic studies on Babesia equi and Babesia caballi infections in Brazil. Vet Parasitol 1999; 85(1): 1-11. http://dx.doi.org/10.1016/ S0304-4017(99)00108-9

Hirata H, Xuan X, Yokoyama N, Nishikawa Y, Fujisaki K, Suzuki $\mathrm{N}$, et al. Identification of a specific antigenic region of the P82 protein of Babesia equi and its potential use in serodiagnosis. J Clin Microbiol 2003; 41(2): 547-551. PMid:12574244 PMCid:PMC149686. http://dx.doi.org/10.1128/JCM.41.2.547-551.2003

Kerber CE, Ferreira F, Pereira MC. Control of equine piroplasmosis in Brazil. Onderstepoort J Vet Res 1999; 66(2): 123-127. PMid:10486829.

Kerber CE, Labruna MB, Ferreira F, De Waal DT, Knowles DP, Gennari SM. Prevalence of equine piroplasmosis and its association with tick infestation in the State of São Paulo, Brazil. Rev Bras Parasitol Vet 2009; 18(4): 1-8. PMid:20040201. http://dx.doi.org/10.4322/ rbpv.01804001

Knowles DP Jr. Control of Babesia equi parasitemia. Parasitol Today 1996; 12(5): 195-198. http://dx.doi.org/10.1016/01694758(96) $10007-7$
Knowles DP, Torioni De Echaide S, Palmer GH, McGuire T, Stiller D, McElwain T. Antibody against Anaplasma marginale MSP-5 epitope common to tick and erytrocytes stages identifies persistently infected cattle. J Clin Microbiol 1996; 34: 2225-2230. PMid:8862589 PMCid:PMC229221.

Kouam MK, Kantzoura V, Gajadhar AA, Theis JH, Papadopoulos E, Theodoropoulos G. Seroprevalence of equine piroplasms and host-related factors associated with infection in Greece. Vet Parasitol 2010; 169(3-4): 273-278. PMid:20138434. http://dx.doi. org/10.1016/j.vetpar.2010.01.011

Kumar S, Kumar Y, Malhotra DV, Dhar S, Nichani AK. Standardisation and comparison of serial dilution and single dilution enzyme linked immunosorbent assay (ELISA) using different antigenic preparations of the Babesia (Theileria) equi parasite. Vet Res 2003; 34(1): 71-83. PMid:12588685. http://dx.doi.org/10.1051/vetres:2002055

Kuttler KL, Goff WL, Gipson CA, Blackburn BO. Serologic response of Babesia equi - infected horses as measured by complement-fixation and indirect fluorescent antibody tests. Vet Parasitol 1988; 26(3-4): 199-205. http://dx.doi.org/10.1016/0304-4017(88)90088-X

Labruna MB, Kerber CE, Ferreira F, Faccini JLH, De Waal DT, Gennari $\mathrm{SN}$. Risk factors to tick infestations and their occurrence on horses in the state of São Paulo, Brazil. Vet Parasitol 2001; 97(1):1-14. http://dx.doi. org/10.1016/S0304-4017(01)00387-9

Mehlhorn H, Schein E. Redescription of Babesia equi Laveran, 1901 as Theileria equi, Schein 1998. Parasitol Res 1998; 84(6): 467-475. http:// dx.doi.org/10.1007/s004360050431

Moretti A, Mangili V, Salvatori R, Maresca C, Scoccia E, Torina A, et al. Prevalence and diagnosis of Babesia and Theileria infections in horses in Italy: A preliminary study. Vet J2010; 184(3): 346-350. PMid:19394253. http://dx.doi.org/10.1016/j.tvjl.2009.03.021

Peckle M, Pires MS, Dos Santos TM, Roier EC, da Silva CB, Vilela JA, et al. Molecular epidemiology of Theileria equi in horses and their association with possible tick vectors in the state of Rio de Janeiro, Brazil. Parasitol Res 2013; 112(5): 2017-2025. PMid:23474658 PMCid:PMC3625414. http://dx.doi.org/10.1007/s00436-013-3360-0

Pfeifer Barbosa I, Bose R, Peymann B, Friedhoff KT. Epidemiological aspects of equine babesioses in a herd of horses in Brazil. Vet Parasitol 1995; 58(1-2): 1-8. http://dx.doi.org/10.1016/03044017(94)00704-G

Machado RZ, Valadão CA, Melo WR, Alessi AC. Isolation of Babesia bigemina and Babesia bovis merozoites by ammonium chloride lysis of infected erythrocytes. Braz J Med Biol Res 1994; 27(11): 2591-2598. PMid:7549981.

Machado RZ, Montassier HJ, Pinto AA, Lemos EG, Machado MR, Valadão IF, et al. An enzyme-linked immunosorbent assay (ELISA) for the detection of antibodies against Babesia bovis in cattle. Vet Parasitol 1997; 71(1): 17-26. http://dx.doi.org/10.1016/S03044017(97)00003-4

Rüegg SR, Torgerson P, Deplazes P, Mathis A. Age-dependent dynamics of Theileria equi and Babesia caballi infections in southwest Mongolia based on IFAT and/or PCR prevalence data from domestic horses and ticks. Parasitology 2007; 134(Pt7): 939-947. PMid:17306055. http:// dx.doi.org/10.1017/S0031182007002405

Santos TM, Roier ECR, Santos HA, Pires MS, Vilela JAR, Moraes $\mathrm{LMB}$, et al. Factors associated to Theileria equi in equids of two microregions from Rio de Janeiro, Brazil. Rev Bras Parasitol Vet 2011; 20(3): 235-241. PMid:21961755. http://dx.doi.org/10.1590/ S1984-29612011000300011 
Schein E. Equine babesiosis. In: Ristic, M. Babesiosis of domestic animals and man. Boca Raton: CRS Press; 1988. p. 197-208.

Shkap V, Cohen I, Leibovitz B, Savitsky, Pipano, E, Avni G, et al. Seroprevalence of Babesia equi among horses in Israel using competitive inhibition ELISA and IFA Assays. Vet Parasitol 1998; 76(4): 251-259. http://dx.doi.org/10.1016/S0304-4017(97)00228-8

Souza AP, Sartor AP, Bellato V, Beatriz Silva AB. Prevalence of Babesia equi antibodies in horses in the Santa Catarina Plateau, Brazil. Cienc Rural 2000; 30(1): 119-121. http://dx.doi.org/10.1590/S010384782000000100019

Tenter AM, Friedhoff KT. Serodiagnosis of experimental and natural Babesia equi and B. caballi infections. Vet Parasitol 1986; 20(1-3): 49-61. http://dx.doi.org/10.1016/0304-4017(86)90092-0
Ueti WM, Palmer GH, Scoles GA, Kappmeyer LS, Knowles PD. Persistently infected horses are reservoirs for intrastadial tick-borne transmission of the apicomplexan parasite Babesia equi. Infect Immun 2008; 76(8): 3525-3529. PMid:18490466 PMCid:PMC2493223. http://dx.doi.org/10.1128/IAI.00251-08

Weiland G. Species-specific serodiagnosis of equine piroplasma infections by means of complement fixation test (CFT), immunofluorescence (IIF), and enzyme-linked immunosorbent assay (ELISA). Vet Parasitol 1986; 20(1-3): 43-48. http://dx.doi.org/10.1016/03044017(86)90091-9

Xuan X, Nagai A, Battsetseg B, Fukumoto S, Makala LH, Inoue N, et al. Diagnosis of equine piroplasmosis in Brazil by serodiagnostic methods with recombinant antigens. J Vet Med Sci 2001; 63(10): 1159-1160. PMid:11714038. http://dx.doi.org/10.1292/jvms.63.1159 